\title{
Genetic variability of multifunctional HC-Pro gene of Lettuce mosaic virus in northern region of India
}

\author{
RITESH MISHRA, RAKESH KUMAR VERMA and RAJARSHI KUMAR GAUR* \\ Department of Biosciences, CASH, Mody University of Science and Technology, Lakshmangarh, Sikar 332 311, Rajasthan, India
}

Received: 26 May 2017/ Accepted: 31 July 2017/ Published online: 30 August 2017

(c) Indian Phytopathological Society 2017

\begin{abstract}
Lettuce mosaic virus (LMV) is an economically important pathogen causing mosaic disease in spinach (Spinacia oleracea). Isolates of LMV originating from different geographical regions in northern India were collected during the survey of 2013-2014. Lettuce mosaic virus (LMV) belongs to Potyviridae family (genus Potyvirus) and is mainly transmitted by aphids. This study covered the genetic variability of Helper component proteinase (HC-Pro) gene of LMV isolates. HC-Pro is multifunctional activity gene, which helps in transmission of virus. The amplified PCR products of $\sim 1.3$ kilo basepairs (kb) were obtained from five different isolates, sequenced and deposited in NCBI GenBank. Two isolates R4 and HR1 from Rajasthan (KJ558375, KM501033), isolate R5 from Haryana (KP635365), isolate R6 from Uttar Pradesh (KP635366) and isolate R4 from Delhi (KP635367)]. The phylogenetic analysis of LMV HC-Pro sequences is showed divergence with other isolates. These isolates showed two different clusters vis-a-vis diversity amongst each other.
\end{abstract}

Keywords: Diversity, HC-Pro, Lettuce mosaic virus, Potyvirus, spinach

Spinach (Spinacia oleracea) is a common edible vegetable crop grown in the temperate region throughout the world. Being a high nutritional value, it is a rich source ( $>20 \%$ of the Daily Value) of vitamin A, vitamin C, vitamin $\mathrm{K}$, magnesium, manganese, folate and iron. According to UC pest management guidelines several plant viruses are reported from spinach (http://www.ipm.ucdavis.edu/ PMG/r732100611.html). These viral diseases may cause growth stunting and yellowing of plants and reduction in the yield. Several society reports (http://www.apsnet.org/ publications/commonnames/Pages/Spinach.aspx) indicated that spinach is infected by as many as 10 viruses belonging to the genus namely; Hybrigeminivirus, Luteovirus, Umbravirus, Fabavirus, Cucumovirus, Potyvirus, Tobamovirus and Tospovirus are reported from worldwide (Fotopoulos et al., 2011).

LMV belongs to the genus Potyvirus and reveals characteristic symptoms of dwarfing, poor heading, mottling, and vein clearing (Lim et al., 2014). Besides the non-persistent transmission by aphid/vector (Myzus persicae and Macrosiphum euphorbiae) it is also transmitted by exchange of contaminated seeds and it depends on cultivars as well as age of seedling at the time of inoculation (Jones et al., 2003). It is possible to differentiate between vector of LMV that land but do not replicate in the crops (transient vectors) (e.g. Myzus persicae Sulzer), transient nonvectors [e.g. Hyalopterus pruni (Geoffroy)], colonizing vectors [e.g. Macrosiphum euphorbiae (Thomas)] and colonizing non-vector species (e.g. Nasonovia ribisnigri Mosley) (Moreno et al., 2007).

*Corresponding author: gaurrajarshi@ hotmail.com
Helper component proteinase (HC-Pro) is a multifunctional protein and it plays an important role in transmission of Potyvirus (Verma et al., 2014; Mishra et al., 2014). HC-Pro is generally divided into three functional domains: domain I (N-terminal domain) whose main function is to mediate aphid transmission, has likely been coevolving with the other two domains, a central region, and a cysteine protease domain (CPD) in the Cterminal region. $\mathrm{N}$ terminal region is required for aphid transmission and efficient genome amplification, the central region for long distance movement in plants (Bihong et al., 2011). PCR based detection method is primary approach for identification the HC-Pro gene of LMV.

Leaf of spinach showing characteristic symptoms of virus infection including dwarfing, mottling, mosaic and vein clearing (Fig. 1) were collected during field

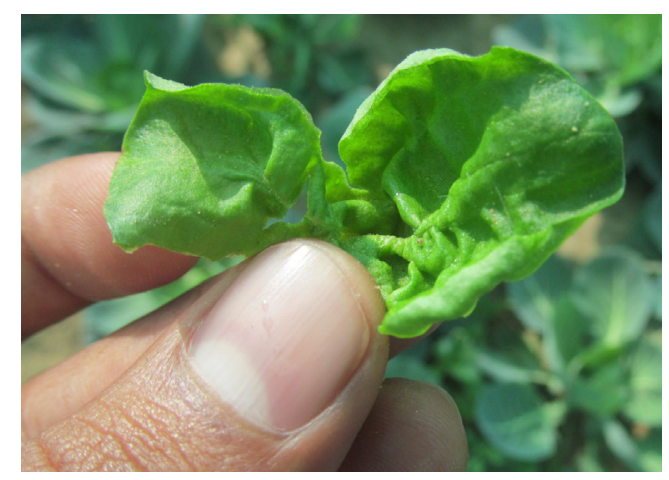

Fig. 1. Spinach leafs showing potyvirus infection (curling in leafs) 
investigation of different regions of northern India (Rajasthan, Haryana, Delhi and Uttar Pradesh) in 201314. All samples of were kept frozen $\left(-20^{\circ} \mathrm{C}\right)$ prior to testing.

Total RNA was extracted from each collected infected leaf using TRISoln Genei ${ }^{(\mathrm{TM})}$ Merk. The leaf samples were homogenized or disrupted in the TRISoln, subsequently, chloroform addition was followed by centrifugation to obtain three distinct layers of lysate. Furthermore, the RNA was precipitated from aqueous phase with isopropanol. The total RNA was reverse transcriptase to first strand of c-DNA by c-DNA synthesis kit (MERK, Genei, INDIA) using Oligo (dT) as primer (followed the manufacturer's instructions). This first strand of c-DNA was used as template to amplify HC-Pro. For the amplification of HC-Pro gene RT-PCR reaction was performed in a total volume of $20 \mu \mathrm{l}$ containing $2 \mu \mathrm{l}$ of first strand cDNA, $2 \mu \mathrm{l}$ of $10 x$ PCR buffer, $1 \mu \mathrm{l}$ of each forward and reverse primer (HPF 5'ATGCATNACACCRNGAAYGATATTCTTG3' and H P R 5' T C A T G C G Y A A A T T I C A C C AGCTGGRGGGTCACG 3') (100 ng/ $\mu \mathrm{l}), 1 \mu \mathrm{l}$ of dNTPs (2.5 mM each), 1.35 unit of Taq polymerase and nuclease free water to a final volume. For the amplification of HCPro gene degenerate primer was used, which are designed after the multiple sequence alignment analysis with 30 different sequences of LMV HC-Pro from NCBI databank.

The PCR products were further cloned into pGEM$T$ vector (Promega, USA), using standard molecular biology procedures. Positive clones were identified by colony PCR as well as restriction digestion of plasmid recombinant. Positive clones (5 recombinants) were sent for custom sequencing.

The HC-Pro sequences were initially analyzed using the BLAST program (http://www.ncbi.nlm.nih.gov/ BLAST). The sequence identity matrix between amino acid sequences and nucleotide sequences was calculated using the BioEdit software version 5.09.04. Amino acid sequences were aligned using Clustal W
(Verma et al., 2016; Yadav and Khan, 2015) and Neighbor-joining tree was generated using MEGA v. 7.0 program (Kumar et al., 2016).

To examine genetic variability of the LMV population in north region of India, field surveys were performed in 2013-2014. Therefore, we have sampled spinach from the fields. All LMV infected samples were identified by RT-PCR. After the PCR amplification we have found $~ 1.3$ $\mathrm{kb}$ band in all five infected samples. After PCR amplification, eluted amplicons were cloned in pGEM-T vector separately and transformed in E.coli DH5 $\alpha$. Near about twenty clones were identified by colony PCR as well as by restriction digestion with EcoRI. After the confirmation all clones (five clones for each) were sequenced (Xcelris Pvt Ltd, Ahmedabad, Gujarat, India) and submitted to the NCBI GenBank [Accession No: KJ558375 (isolate R4 from Rajasthan), KM501033 (isolate HR1 from Rajasthan), KP635365 (isolate R5 from Haryana), KP635366 (isolate R6 from Lucknow, Uttar Pradesh) and KP635367 (isolate R4 from Delhi)].

BLAST analysis LMV Indian isolates HR1, R5 and R7 showed $90 \%, 78 \%$ and $77 \%$ identity respectively with LMV strain E from France. R4 and R6 isolates showed $75 \%$ and $76 \%$ sequence identity with LMV isolate Tn515ev Tunisia and LMV isolate muju respectively. Sequence identity matrix analysis of the 5 Indian HC-Pro isolates revealed $60-82 \%$ nucleotide sequence identity themselves and other LMV isolates compared in this study. Comparative analysis of amino acid sequences showed $70-99 \%$ sequence identity themselves and other LMV isolates (Table 1). The phylogenetic analysis of LMV $\mathrm{HC}$-Pro sequence showed the ancestry and evolutionary relationship with other isolates LMV Brazil isolates and LMV France strain E (Fig. 2).

The sequence identity matrix showed the clear diversity among Indian isolates (under this study) at nucleotide and amino acid level. Similar types of genetic variability study have been described for the HC-Pro genes of sugarcane streak mosaic virus (SCSMV). Phylogenetic analysis of LMV isolates from north India

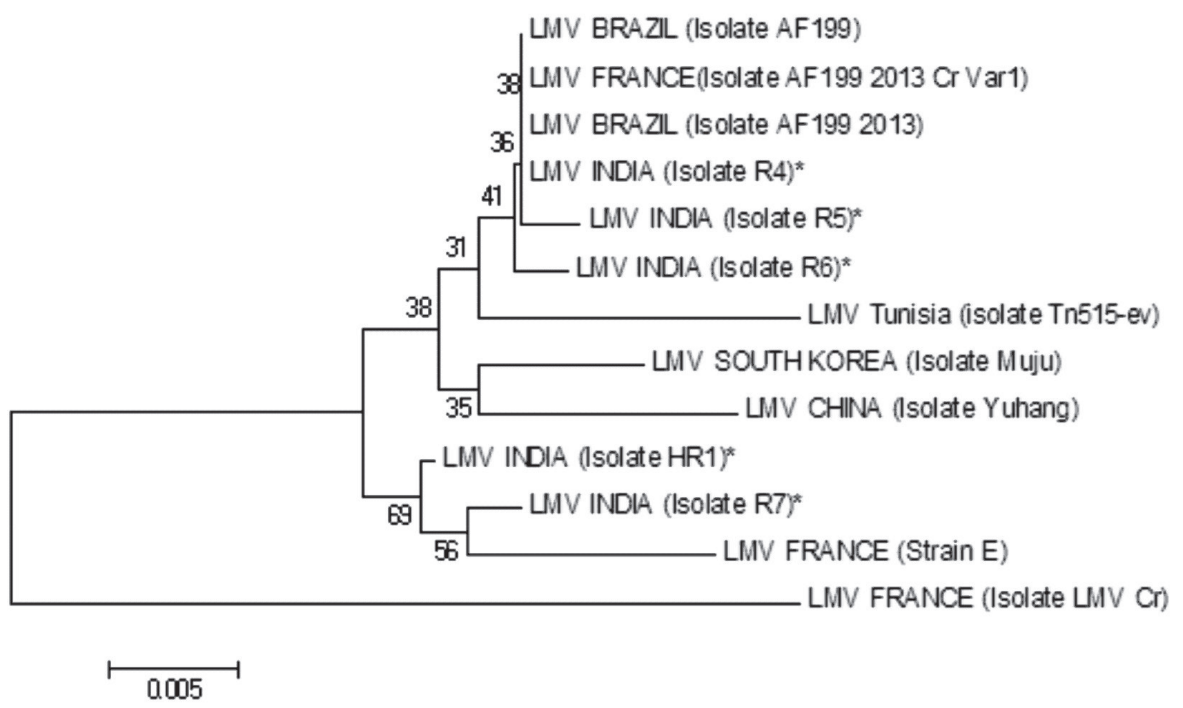

Fig. 2. Cladogram of LMV HC-Pro by Neighbour-joining (NJ) method. (*) mark indicates this study sequences 
Table 1. Percent nucleotide (Above the diagonal line) and amino acid (below the diagonal line) between HC-Pro genes of Lettuce mosaic virus (LMV) isolates from India (this study)

\begin{tabular}{lccccc}
\hline LMV isolates & HR1 & R4 & R5 & R6 & R7 \\
\hline HR1 & 100 & 82.1 & 76.8 & 76.0 & 61.1 \\
R4 & 99.3 & 100 & 76.6 & 80.7 & 59.7 \\
R5 & 99.0 & 99.7 & 100 & 75.8 & 61.2 \\
R6 & 99.0 & 99.7 & 99.5 & 100 & 60.1 \\
R7 & 70.0 & 69.3 & 69.3 & 69.0 & 100 \\
\hline
\end{tabular}

(under this study) showed in two separate clusters in which isolates HR1 and R7 from Rajasthan and Delhi respectively in one cluster and rest of three isolates $R 4$, R5 and R6 from Rajasthan, Haryana, Lucknow (Uttar Pradesh) respectively in another cluster. HC-Pro of LMV Indian isolate HR1 and R7 showed phylogenetic relationship related with LMV France (strain E) and another hand side LMV isolate R4 shows clustering with LMV Brazil isolate AF 1992013 France isolates.

Several LMV isolates have been characterized from different geographical regions and analysed on the basis of capsid protein (CP) genes (Lim et al., 2014). There are some reports for HC-Pro genetic diversity of different species of potyvirus (Jaroszewska et al., 2013) but in our knowledge, for LMV, this is the first evidence of phylogenetic analysis and diversity of HC-Pro in India. The study presented shows the diversity of Lettuce mosaic virus in Northern India. Our results will certainly help to develop strategies for developing resistance varieties against LMV and it might be useful in future efforts to control the disease; particularly should there be further epidemics.

\section{ACKNOWLEDGEMENTS}

The authors are thankful to Department of Biotechnology, New Delhi (BT/PR14902/BRB/10/889/2010) for providing financial support.

\section{Conflict of Interest}

The authors declare that they have no conflict of interest.

\section{REFERENCES}

Bihong G, Jinzhon $L$ and Keqiong $Y$ (2011). Structure of the autocatalytic cysteine protease domain of potyvirus helpercomponent proteinase. J. Biol. Chem. 286: 21937-21943.

Chen $\mathrm{J}$ and Adams MJ (2001). A universal PCR primer to detect members of the Potyviridae and its use to examine the taxonomic status of several members of the family. Arch. Virol. 146: 757-766.

Fotopoulos V, Dovas Cl and Katis NI (2011). Incidence of viruses infecting spinach in Greece, highlighting the importance of weeds as reservoir hosts. J. Plant Pathol. 93: 389-395.

Jaroszewska BH, Fares MA and Elena SF (2013). Molecular evolution of viral multifunctional proteins: The case of potyvirus HC-Pro. J. Mol. Evol. 78: 75-86.

Jones AT, Robinson DJ, Boonham N and Mumford R (Ed.) and Le Gall O (2003). Lettuce mosaic virus. In: CMI/AAB description of plant viruses. Wellesbourne: Association of Applied Biologists UK, 399p.

Kumar S, Stecher G and Tamura K (2016). MEGA7: Molecular Evolutionary Genetics Analysis Version 7.0 for Bigger Datasets. Mol. Biol. Evol. 33: 1870-1874.

Lim S, Zhao F, Yoo RH, Igori D, Lee SH, Lim HS and Moon JS (2014). Characteristics of a Lettuce mosaic virus Isolate Infecting Lettuce in Korea. The Plant Pathol. J. 30: 183187.

Mishra R, Verma RK, Sharma P, Choudhary DK and Gaur RK (2014). Interaction between viral proteins with the transmission of Potyvirus. Arch. Phytopathol. Plant Prot. 47: 240-253.

Moreno A, Nebreda M, Diaz BM, Garcý ìa M, Salas F and Fereres A (2007). Temporal and spatial spread of Lettuce mosaic virus in lettuce crops in central Spain: Factors involved in Lettuce mosaic virus epidemics. Ann. Appl. Biol. 150: 351-360.

Verma RK, Mishra R and Gaur RK (2014). Systemic infection of Potyvirus: a compatible interaction between host and viral proteins, In: Gaur RK and Sharma P. (Eds). Approaches to plant stress and their management, pp. 353363. Springer, Berlin, Germany.

Verma RK, Mishra R and Gaur RK (2016). Genetic variability of the replicase (NIb) gene of papaya ringspot virus in Northern India indicates common ancestry with isolates from China and Taiwan. J. Plant Pathol. 98: 105-110.

Yadav N and Khan JA (2015). Molecular identification of a new strain Narcissus yellow stripe virus associated with severe mosaic disease of Narcissus from India. Indian Phytopath. 68: 444-448. 